\title{
Correction to: Validation of a QTL for Grain Size and Weight Using an Introgression Line from a Cross between Oryza sativa and Oryza
} minuta

Yue Feng ${ }^{*}$, Xiaoping Yuan, Yiping Wang, Yaolong Yang, Mengchen Zhang, Hanyong Yu, Qun Xu, Shan Wang, Xiaojun Niu and Xinghua Wei*

\section{Correction to: Rice (2021) 14:43}

https://doi.org/10.1186/s12284-021-00472-1

In the original publication of the article, the supplementary figure 1 was published incorrectly. The corrected supplementary figure is provided in this correction article. The original article has been corrected.

\section{Supplementary Information}

The online version contains supplementary material available at https://doi. org/10.1186/s12284-021-00545-1.

Additional file 1. Figure S1: Comparison of grain sizeand cell number in the outer spikelet hulls along the vertical and lateraldirection between NIL-qGL7Nipand NIL-qGL7IL188. Scale bar, $1 \mathrm{~mm}$. A,Mature grains of NIL-qGL7IL188(left) and NIL-qGL7Nip(right). B-C, The cellnumber in the longitudinal and lateral direction of outer spikelet hulls.

Published online: 20 December 2021

\section{Reference}

Feng Y et al (2021) Validation of a QTL for Grain Size and Weight Using an Introgression Line from a Cross between Oryza sativa and Oryza minuta. Rice 14:43

\section{Publisher's Note}

Springer Nature remains neutral with regard to jurisdictional claims in published maps and institutional affiliations.
The original article can be found online at https://doi.org/10.1186/s12284021-00472-1.

*Correspondence: fy_555500@163.com; weixinghua@caas.cn

Chinese National Center for Rice Improvement and State Key Laboratory

of Rice Biology, China National Rice Research Institute, Hangzhou 310006,

China (c) The Author(s) 2021. Open Access This article is licensed under a Creative Commons Attribution 4.0 International License, which permits use, sharing, adaptation, distribution and reproduction in any medium or format, as long as you give appropriate credit to the original author(s) and the source, provide a link to the Creative Commons licence, and indicate if changes were made. The images or other third party material in this article are included in the article's Creative Commons licence, unless indicated otherwise in a credit line to the material. If material is not included in the article's Creative Commons licence and your intended use is not permitted by statutory regulation or exceeds the permitted use, you will need to obtain permission directly from the copyright holder. To view a copy of this licence, visit http://creativecommons.org/licenses/by/4.0/. 